\title{
Multi-Disciplinary Approach in Indonesian Islamic Higher Education: A Western Perspective upon Epistemological Problem, Challenge, and Critique
}

\author{
Auliya Ridwan \\ UIN Sunan Ampel Surabaya \\ aridwan@uinsby.ac.id
}

\begin{abstract}
The development of several Institute of Islamic Studies into Islamic Universities brings consequences to living religious disciplines vis-à-vis secular disciplines. A multi-disciplinary approach is adopted by positioning al-Quran and Hadits as the foundation of scientific development. This paper attempts to bring western perspective in examining epistemological issues in Indonesian Islamic higher education's multi-disciplinary approach, its challenges, and critiques. Religious discipline's domain cannot fully be examined from secular discipline's framework, as it will result in contra-productive confrontation between the two authorities. Therefore, the challenge for this approach is defining which are autonomous areas in the two domains and which is the intersection. Pragmatically, this approach must result in new genres, which are more productive for the development of mankind civilization.
\end{abstract}

\begin{abstract}
Abstrak
Perkembangan beberapa Institut Agama Islam menjadi Universitas Islam membawa konsekuensi untuk menghidupkan disiplin keagamaan secara beriringan dengan disiplin ilmu sekuler. Pendekatan multi-disipliner diadopsi dengan menempatkan al-Quran dan Hadits sebagai fondasi pengembangan keilmuan. Tulisan ini mencoba membawa perspektif barat dalam menelaah masalah epistemologi pendekatan multidisipliner di lembaga PT Islam di Indonesia, tantangan-tantangannya, dan kritiknya. Disiplin keagamaan tidak dapat sepenuhnya ditelaah dari disiplin sekuler karena akan menimbulkan konfrontasi kontra-produktif dari kedua otoritas. Dengan demikian, tantangan pendekatan ini adalah mendefinisikan mana wilayah otonom di kedua domain dan mana wilayah irisannya. Secara pragmatis, pendekatan ini harus menghasilkan genre-genre keilmuan baru yang lebih produktif dalam kontribusinya bagi perkembangan peradaban manusia.
\end{abstract}

Keywords: Islamic Higher Education, Multi-disciplinary Approach, Epistemology, Challenge, Critique. 


\section{A. Introduction}

In the last decade, more and more Indonesian Institute of Islamic Studies (IAIN) converted into Islamic University (UIN). As the consequence, Islamic studies must go on together with at least two nonreligious-studies school (fakultas) in each university. The consequence of the transformation from IAIN to UIN is not only in the previously mentioned change in the university "hard structure", but also in its philosophical foundation on how the Islamic university integrate Islamic disciplines with secular one. Several efforts have been made by each university to construct an inter-connection between religious and secular disciplines. For instance, UIN Yogyakarta developed spider-net diagram ${ }^{1}$ to put al-Quran and Hadits as the core scientific approach and UIN Surabaya comes with Twin Tower model ${ }^{2}$ to do the same efforts. The inter-connection efforts are appreciated by insiders but it probably leads to disagreement or dissatisfaction from outsiders. This paper attempts to examine the new scientific paradigm in Islamic university from Western philosophical frameworks. Epistemology, challenges, and critiques are the focuses in this paper.

I would start this paper with a short description of how Muslim in general deal with science and religion (read: Islam) over period of time. This description is purely what I got from many conversations with Muslim groups with different point of views. I cannot say that Muslims have the same idea about their religion. In general, I would categorize them into three groups: textual, contextual, and spiritual group. Examples are also provided to support this categorization. I divide the typology based on how they interpret religious texts (Al-Quran and Hadith) and on how they behave in social life. The textual group mostly has literal interpretation to the texts. Spiritual group interpret the texts with theosophical concept and personal feeling as the "measuring stick" of truth. Last, contextual group is the community who understand religious texts based on the context at the time of certain religious texts were revealed. The following quotes reflect how the idea of salvation in Islam is interpreted differently (textually, theosophically, and contextually) due to different horizons of its interpreters.

1 UIN Sunan Kalijaga Yogyakarta, "Core Values," accessed 2017. http://uinsuka.ac.id/page/universitas/29-core-values.

2 UIN Sunan Ampel Surabaya, "Paradigma Keilmuan," accessed 2017. http://www.uinsby.ac.id/id/251/paradigma-keilmuan.html. 
"Salvation, then, required living a life in conformity with the law. For others, real knowledge was esoteric and mystical, and hence the path to salvation lay in seeking the right teacher and being initiated into devotional practices leading to union with God. Still others thought real knowledge consisted of a rational understanding of God's nature and attributes, His creation of the world, its dependency on Him, and His bounty and mercy to the creatures of this world as manifested in prophecy. For them, salvation lay in the practices instituted by prophets, provided that the performance of these practices was grounded in rational knowledge."3

The change in teaching Islam paradigm domination in Indonesia is influenced by the present of science-technology and religious way of life at the same time. This phenomenon can be briefly seen in almost all public schools where IPTEK-IMTAQ becomes one of their educational visions. ${ }^{4}$ Recently, many Indonesian academics still believe in religion although they have a high degree education and good understanding about science. This implies that the development of science and technology does not necessarily result in the abolition of religious practices. In other words, faith and piety are foundational in the modernizing Indonesian Islamic world, to counter the "secularization of consciousness" which marks much of the modern world. ${ }^{5}$

The question that may arise later is how Indonesians are possible to be religious and highly educated in science at the same moment. I will answer this question with the fact that people regularly do not conflict between science and religion. In line with this phenomenon, Gould in his Non-overlapping Magisterial (NOMA) theory stated that both disciplines are not necessarily at war as they have different subject matter. ${ }^{6}$ In NOMA theory, magisterium of science focuses on empirical realm and

\footnotetext{
3 Alnoor Dhanani, "Muslim Philosophy and the Sciences," (2006), accessed 05/12/2017, http://iis.ac.uk/academic-article/muslim-philosophy-and-sciences.

4 IPTEK-IMTAQ stands for "Ilmu Pengetahuan dan Teknologi - Iman dan Taqwa" (Science and Technology - Faith and being Godly).

5 Elisabeth Jackson and Lyn Parker, "'Enriched with Knowledge': Modernisation, Islamisation and the Future of Islamic Education in Indonesia," RIMA: Review of Indonesian and Malaysian Affairs 42, no. 1 (2008).

6 George Karuvelil, "Science of Religion and Theology: An Existential Approach," Zygon® 47, no. 2 (2012): 419, http://dx.doi.org/10.1111/j.1467-9744.2012.01263.x.
} 
explanation why facts work in certain way (theory); on the other hand, magisterium of religion covers questions of ultimate meaning and moral value. $^{7}$ However, the conflict between science and religion is always visible due to its existence in humans mind. In this discourse, Bertrand Russell mentioned that the conflict is actually conflict between authority and observation. ${ }^{8}$ I would say that religion as authority provides information of ultimate truth and science as observation needs verification how the ultimate truth can be seen as scientific truth.

The discourse above represents what happens in Western countries. Let's go back to Indonesia; the conflict does not regularly happen as Indonesian academics see the two disciplines as different entities and should not work together. For example, during the dialogue on new national education curriculum, Bandung Institute of Technology scientists criticized the fact that there is too much religious substance in physics curriculum. ${ }^{9}$ In the scientists' perspective, when natural science is taught along with religious subject matter, natural science information become holy and cannot be debated. ${ }^{10}$ From this discussion, we can see that the scientists do not refute religious teaching, but the teaching should be delivered separately from science. I would argue that the conflict between science and religion does not intensively happen as people creates demarcation line between the domains.

Along with the growth of science and technology, Indonesians experience -in Nur Syam's word- "longing" to be more religious and finding relationship between religion and actual social phenomena. ${ }^{11}$ In

${ }^{7}$ IbGeorge Karuvelil, "Science of Religion and Theology: An Existential Approach," Zygon® 47, no. 2 (2012): 419, http://dx.doi.org/10.1111/j.1467-9744.2012.01263.x.

${ }^{8}$ IbiGeorge Karuvelil, "Science of Religion and Theology: An Existential Approach," Zygon® 47, no. 2 (2012): 419, http://dx.doi.org/10.1111/j.1467-9744.2012.01263.x.

9 Didit Putra Erlangga Rahardjo, "Kurikulum 2013 Ditelanjangi Di Itb," accessed. http://edukasi.kompas.com/read/2013/03/13/19402224/Kurikulum.2013.Ditelanjangi.di. ITB.

10 Didit Putra Erlangga Rahardjo, "Kurikulum 2013 Ditelanjangi Di Itb," accessed. http://edukasi.kompas.com/read/2013/03/13/19402224/Kurikulum.2013.Ditelanjangi.di. ITB.

${ }^{11}$ Nur Syam is rector emeritus of IAIN Sunan Ampel Surabaya who -in his rector position era- introduced the concept of "Twin Tower". He adds that nowadays is the resurgence era of religion. According to him, the positivists' claim -that religion will be left by humans as the raise of science- is not proven to be. Religion now becomes subject matter of many humanities and social science. Since long time ago, social scientist like E.B. Taylor, J.J. Frazer, R.R. Marett, Karl Marx, Durkheim, and Weber 
order to respond this request, higher educational institution, particularly Islamic University, must begin to formulate interdisciplinary studies that provide meaningful room for religion in social life. In my opinion, innovation in teaching religion is a must because textual religious teaching delivery may be stuck in vis-à-vis position with contemporary language of curiosity. People demand to know how their religion can be understood in today's language.

The remaining problem of this dream is its epistemological problem. Multi-disciplinary approach in Islamic studies -such as Twin Tower model in UIN Surabaya- is still struggled with how to equal science and religion through dialogue. The Twin Tower model is purposed to build disciplinary structure in which religious studies, social science studies, and natural science studies are developed properly without superiority and inferiority one to another. ${ }^{12}$ According to Syam, the foundations of the disciplinary studies are Al-Quran and Hadith; one tower consists of pure Islamic studies (like Tafseer, Hadith, Fiqh, Kalam, and Tasawuf) and applied ones (like Dakwah and Tarbiyah); another tower made up of natural science, social science, and humaniora. ${ }^{13}$ The disciplinary structure must be put on Quranic-Hadith foundation because the products will be prophetic social science, prophetic natural science, and prophetic culture and humaniora studies. ${ }^{14}$ These products are the "bridge" between the two towers. Syam mentioned that those "transtheoretical" genres are purposed to not only develop theory, but also to develop community. ${ }^{15}$

In this paper, I deliver dialogue from several perspectives about science and religion. This paper is not the final answer of how the multidisciplinary model in Islamic higher education -such as, again, Twin Tower model- should work. However, from several different perspectives

dan have also put religion not as doctrinal study subject matter, but social study one. Nur Syam, "Membangun Keilmuan Islam Multidisipliner," accessed, http://nursyam.uinsby.ac.id/?p=754.

12 Nur Syam, "Membangun Keilmuan Islam Multidisipliner," accessed, http://nursyam.uinsby.ac.id/?p=754..

13 Nur Syam, "Membangun Keilmuan Islam Multidisipliner," accessed, http://nursyam.uinsby.ac.id/?p=754.

14 Nur Syam, "Membangun Keilmuan Islam Multidisipliner," accessed, http://nursyam.uinsby.ac.id/?p=754.

15 Nur Syam, "Membangun Keilmuan Islam Multidisipliner," accessed, http://nursyam.uinsby.ac.id/?p=754. 
I would identify how the model potentially can be failed or can be beneficial as it is expected. I start the discussion with the idea of science in Western perspective and I will examine how modern science can deal with religion issues in terms of academic vocation in America. Afterwards, I would deliver the idea of contact and confirmation between religion and science which involves several philosophical vies from Western philosophers and Islamic ones. Finally, I will provide critique of the relationship between science and religion in pragmatism framework.

\section{B. From Religion to Science: Learning from Academic Vocation in America}

Before talking about academic vocation in America, I would begin this section with how Western scientists see science. Karl Popper delivered the concept of science in way of conventionalism and falsificationism. Subsequently, he argued -by confronting both isms- that natural phenomena are not always regular. Some people may not question about the irregularity because they believe in Ultimate Explanation (in this paper context, Ultimate Explanation can be in form of religious texts). Popper in his purpose of science offered "modified essentialism" to deal with the ultimate explanation.

1. Conventionalism

Let's start out with conventionalism. For those who are influenced by conventionalism, every natural phenomenon is wellordered regulation by law of nature. The school of thought called Conventionalism sees the objections -in what Popper said- as "simplicity of the world". ${ }^{16}$ By way of explanation, Popper said that conventionalist sees the world as simple as revealed in the law of physics. ${ }^{17}$ In addition, Kant figured this simplicity by saying that our ability to understand phenomenon imposes the laws on the nature. Strictly speaking, conventionalist constructs simple laws and finds evidences on the nature. ${ }^{18}$ As a confirmation to Kant's thought, conventionalist also says that the world is a creation of human thought; and conventionalists see the world not as a picture of the

\footnotetext{
${ }^{16}$ Karl Raimund Popper and David Miller, A Pocket Popper, Fontana Pocket Readers (London: Fontana, 1983), 143.

17 Karl Raimund Popper and David Miller, A Pocket Popper, Fontana Pocket Readers (London: Fontana, 1983).

18 Karl Raimund Popper and David Miller, A Pocket Popper, Fontana Pocket Readers (London: Fontana, 1983).
} 
world itself but logical construction by "laws of nature". ${ }^{19}$ This conception leads to define entities in the world as science.

The product of conventionalism is clarification between theory and experiment. In other words, the method of thinking is inductive. Inductive method begins with specific facts to general principles. Later, the principles generalize the rules to broader phenomena. As a result, the product is characterized by the existence of consistent mechanical to examine phenomena. As regularity plays important role in this ism, the product of conventionalism is consistence of phenomena. Therefore, conventionalism is not likely to be successful in attempting to find inconsistence.

Now, let's talk about religion in conventionalism perspective. Conventionalism needs theory and experiment to confirm the truth of a theory. In this discussion, I would define religion as religious texts. If we want to put certain verses as specific facts, then the problem is which interpretation we will use to translate the words of God into human words. Never ended debate will occur to decide which interpretation that will work on a correct context. Due to this difficulty, I would say, Indonesians do not conflict religion and science because religion does not work in a way of how science works.

\section{Diagram 1. Substituting Religious Interpretation in Inductive Logics?}

Specific facts $\rightarrow$ generalization of rules to broader phenomena

Religious verses (with multi-interpretation) $\rightarrow$ many kinds of generalization*

*(may work for some phenomena and fail for some others in different contexts)

\section{Falsificationism}

Popper clearly distinguished between falsifiability and falsificationism. He defined falsifiability as "criterion for the empirical character of a system of statements"; concerning falsification, "special rules must be introduced which will determine under what conditions a system is to be regarded as falsified". Furthermore, falsifiability or testability becomes the demarcation between what is categorized as science and pseudo-science. This means that falsifiability is an entity that can show how a natural

19 Karl Raimund Popper., 144.

20 Karl Raimund Popper 150. 
scientific law is possibly false. Furthermore, something that is considered falsifiable doesn't mean that it is false. However, if it is false, one can show what the fault is.

In this sense, one also cannot test religious texts since the texts itself is not testable. It is not testable because we cannot decide what exactly and absolutely certain verses mean. However, one can make use falsaficationism in order to observe social phenomena as impacts of religious life. The question that may arise is like "is it true that religious people more resistant stress than unreligious ones?"

\section{Diagram 2. Falsifiable and Unfalsifiable:}

Falsifiable: "religious people are more resistant to stress than unreligious ones"* *this claim is falsifiable since the fact that many religious people claim that they feel calm due to being religious.

Unfalsifiable: "human beings cannot see physical body of God"** **this is unfalsifiable since this cannot be proven true or false.

\section{The purpose of science}

Different scientists have different aims for the science itself. For one scientist, the aim of science is providing satisfactory explanation by explaining causality in a set of statement; and another one aims science to form explanation in the narrower sense of the world. $^{21}$ The first aim is likely to be true. With sense of "universal laws which are testable" (falsifiable) human can interpret the causality in a statement as a reproducible effect.

Popper considers the aim of science is to provide satisfactory explanation. Satisfactory in Popper's mind is highly testability of science. $^{22}$ This means that the more satisfying a science, the more testable it is. The testability will lead to a research that can go for ever unless scientists arrive to a condition called Ultimate Explanation". ${ }^{23}$

Ultimate explanation means being not capable for any further explanation, but it doesn't need further explanation. ${ }^{24}$ The satisfactoriness can be provided by essentialists who see the

\footnotetext{
Karl Raimund Popper, 162.

Karl Raimund Popper 164.

Karl Raimund Popper 164.

${ }^{24}$ Karl Raimund Popper 164.
} 
existence of essence beyond existing phenomena. When we explain a phenomenon by using its essence, then there will be no more questions can be raised. However, Popper was a realist who rejected all kind of question about what essence is, or what the world is. Because of the satisfactoriness provided by essentialism, science will not grow anymore as humans lose their curiosity.

As the rejection to essentialists, Popper came with the idea of modified essentialism. This is what he called as the "third view". ${ }^{25}$ This third view characterizes the fact that an explanation can be further explained and essence cannot be a self-explanation of itself. Next, one has to stay away from animism. It is the fact that animism -in Popper's perspective- explains nothing, but it must lead human being to shun relational a priori valid based on an assumed fact. ${ }^{26}$ In other words, animism must lead human curiosity to provide actual observed facts.

By using this third view, I would say that contemporary religious people should not be satisfied with explanation that, for example, they become more resistant from stress just because God stays close with their soul. However, people should find the explanation beyond the language of religion. In other words, one need revolutionary way of beliefs. Therefore, religious people should make use of science to translate religious language into contemporary language. Mohammad Sholeh's work on Tahajud (night prayers) within the framework of psycho-neuro-immunology is best representing how Indonesian Islamic scholar translated religious interpretation into scientific experiments. ${ }^{27}$

The next question is "is the translation effort always successful?" The word "successful" here means science has positive confirmation to the religious phenomena. Let's learn from academic vocation in America with a question, "where spirited inquiry comes from?" Schwehn begins with a statement that the spirit of inquiry is not only coming from cognitive skills, but also virtues that sustain to

\footnotetext{
Karl Raimund Popper, 165.

Karl Raimund Popper. 166.

${ }^{27}$ Moh. Sholeh, Terapi Shalat Tahajud Menyembuhkan Berbagai Penyakit (Jakarta: PT. Mizan Publika, 2012).
} 
enable inquiry to move in particular direction. ${ }^{28}$ This concept is very Weberian and this dominated the past of America. The domination is briefly seen in community who are self-consciously religious in character. ${ }^{29}$ The problem with this concept is how to explain the relationship between religion and higher learning. ${ }^{30}$ I would employ this concept in terms of developing discussion of science from religious beliefs. For those who believe that religion encourage humans to find truth through science, and then the question is "is it possible to find the same truth when someone does not begin his investigation from religious starting point?"

To answer this question, I would begin with David Hume's definition of virtues and his experience in Christianity. Hume defines virtues as "qualities of character that fall under four basic headings: those agreeable to oneself, those agreeable to others, those useful to oneself, and those useful to others". ${ }^{31}$ As a consequence of this statement, all kinds of self-denial and many other monkish trainings are not agreeable to oneself and others, nor useful to oneself or others, because those all kinds of training cannot advance human life. $^{32}$ In short, Hume argued that Christianity is not a set of teaching; it is no more than a set of way of life. ${ }^{33}$ By using Hume philosophical framework, it can be concluded that religion should be separated from development of science because developing science and going along with religion means to give human beings no freedom since religion will lead scientific development along the corridor of science. James Gustafson argued that our knowledge depends on others' perception about something; however, we are not supposed to believe others' perception uncritically. ${ }^{34} \mathrm{He}$ also stated, "we typically believe what we are questioning and at the same time question what we are believing". 35 In this sense, it is clear that one

${ }^{28}$ Mark R. Schwehn, Exiles from Eden: Religion and the Academic Vocation in America (New York: Oxford University Press, 1993), 44.

29 Mark R. Schwehn, Exiles from Eden: Religion and the Academic Vocation in America (New York: Oxford University Press, 1993), 44..

${ }^{30}$ Mark R. Schwehn 46.

${ }^{31}$ Mark R. Schweh, 46

${ }^{32}$ Mark R. Schweh, 46

${ }^{33}$ Mark R. Schweh, 46

${ }^{34}$ Mark R. Schweh, 49

${ }^{35}$ Mark R. Schweh, 49 
need to criticize knowledge that he got form others and at the same time be prepared to abandon some beliefs.

Bringing Western perspective to position religion vis-à-vis science seems to be quite dynamic in terms of making use religious information as the foundation of scientific development. From this perspective, science and religion will be in a pendulum position in which at the end one side will be much more believed than the other side. The effort of multi-disciplinary approach in Indonesian Islamic higher education from western perspective must put human curiosity to gain observed facts from a priori constructed religious views. Therefore, what can be observed from religious phenomenon is a domain where scientific inquiry can work in it. Probably it is what in Amin Abdullah's term called "interconnectedness of disciplines". ${ }^{36}$ The area of faith, for instance, cannot be observed scientifically due to unfalsifiable. However, this domain can be a foundational ethical direction of where science is used for.

\section{Contact and Confirmation Between Science and Religion}

It cannot be denied that religion and science are in conflict to each other in the sake of truth. This is because their way of deliveries is not the same. Religion brings the "Ultimate Truth" without explaining how to explain the truth. On the other hand, science seeks for truth by building foundations on foundations where empirical processes are visible. Science and religion are contrast to each other, because science deals with natural realm facts and religion brings the ultimate meaning of those facts. Can we contact religion and science? If so, in what area? Is it confirmation from one to another?

Let's take one example from Haught, "is religion opposed to science?". 37 Haught answers the question by providing approaches in terms of conflict, contrast, contact, and confirmation. I do not want to talk about conflict and contrast because the answer is already clear. In contact approach, Haught mentions that it is clear logical distinction between science and religion; however, theologians always bring implicit

\footnotetext{
${ }^{36}$ Ronald Lukens-Bull, Islamic Higher Education in Indonesia: Continuity and Conflict, First edition. ed. (New York: Palgrave Macmillan, 2013), 50.

37 John F. Haught, Science and Religion: From Conflict to Conversation (New York: Paulist Press, 1995), 9.
} 
cosmological assumption in their talk about God. ${ }^{38}$ From this contact approach, theologian can preserve their religious teaching and they also can broaden their faith horizon. ${ }^{39}$ And for sure, broader religious horizon can deepen our understanding about the universe. Therefore, religious people should not be skeptical to science. In confirmation approach, Haught totally agree with the notion that religion cannot add anything to the scientific discoveries. However, religion has put our trust in reality's over all rationality. ${ }^{40}$ In this case, religious people believe that the universe is well-regulated because the intellectual agent controls it. As a confirmation, science shows the regularity in laws of physics.

Haught's explanation above can a little bit relieve conflict between science and religion relationship. However, we can see in his explanation that both the contact and confirmation approaches are based on religious notion. In the contact approach, theologians can broaden their faith horizons and explain about God with cosmology. It means that theologians make use theological claim as foundation and cosmological claim as strengtheners of the theological one. If theologians can do so, can scientists do the opposite, putting scientific claim as foundation and putting theological claim as the strengtheners? Let's now see the confirmation approach by Haught. His notion of putting trust over rationality means making human beings believe to the claim even though the scientific confirmation is not coming yet. This also means that religious claims once again play role in building human beings' trust that something will happen. This can lead human beings to seek for confirmation as religious claims put the trust in the beginning. In short, the research will not be neutral since it is influenced by religious claim.

This never-ending debate leads to a question "How can human beings make room in the age of science?" Michael Ruse in his Science and Spirituality delivers it in a way of believers and non-believers. In a discussion of soul, believers (read: Christians) believe claims that God created humans from the image of Him. ${ }^{41}$ The most important part of the image of God is the ability to think -the soul and its connection to God. ${ }^{42}$

\footnotetext{
38 John F. Haught, 18.

${ }^{39}$ John F. Haught, 19

40 John F. Haught, 23

${ }^{41}$ Michael Ruse, Science and Spirituality: Making Room for Faith in the Age of Science (Cambridge England; New York: Cambridge University Press, 2010), 214.

${ }^{42}$ Michael Ruse, Science and Spirituality: Making Room for Faith in the Age of Science (Cambridge England; New York: Cambridge University Press, 2010), 214.
} 
As the concurrence of this beliefs, Karl Barth said that we have to have "the ability to know God, to be aware as ourselves as beings, and to understand our relationship to God". ${ }^{43}$ This means that by soul, human being can "meet" God by being someone for Him and in relation to Him. ${ }^{44}$ This attitude will much have influenced how people behave with modern science. Believers will go deep into theological discussion about what soul is and its relation to God and how to be beings. Ruse in his book much positioned religion in a way of building morality by understanding the existence of human being.

What can we say the theologian notion of soul in the light of science? If someone is not a believer, he will reject most of the idea. In addition, in the light of modern science, someone should also reject it. The more we are talking about religion, the more mystery we have. Therefore, Ruse argued that theological problems need theological answer. ${ }^{45}$ However, it does not mean that he decided to separate religion and science. Ruse argued that we cannot decide a priori to the relationship before inquiry begins, especially as science sail and develop. ${ }^{46}$ When science and religion meet in the boundaries, each of them must across the border to see each other. Therefore, Christianity cannot simply ignore the achievement of science and conversely religion claims should also be infused with a very up-to-date science. ${ }^{47}$ The final answer of Ruse about science and religion relationship is a challenge to across each border. I would see this conclusion as not only an openended answer, but also an allurement to for believers to respect scientific achievement and vice versa.

How do Muslim philosophers struggle with the issue of science and religion? It is the fact that Muslim philosophers in medieval era were much influenced by Hellenistic philosophy which was translated into Arabic. The appreciation of knowledge and love learning can be seen in al-Kindi writing: "We ought to be ashamed of appreciating trust and of acquiring it wherever it comes from, even if it comes from races distant and nations different from us". ${ }^{48}$ Also, they made use the Hellenistic

\footnotetext{
${ }^{43}$ Michael Ruse, 216

${ }^{44}$ Ibid Michael Ruse, 216

${ }^{45}$ Michael Ruse, 221

${ }^{46}$ Michael Ruse, 235

${ }^{47}$ Michael Ruse, 216

${ }^{48}$ Dhanani, 6.
} 
philosophy to understand the rationale understanding of God's nature and attributes. ${ }^{49}$ From those statements, it can be concluded that the characteristic of Islamic Hellenistic philosophy is to find confirmation between nature as God's creature and logics. To do this, Islamic philosopher like al-Kindi was not reluctant to learn from outside religious teaching. This means that the philosophers put open-minded characteristics in development of science.

Mohamad Sholeh, an IAIN Surabaya scholar, criticized that contemporary scholars -religious scholars and scientific ones- practiced "dichotomic logics" which science and religion must work in separated path. ${ }^{50}$ Something that he did was a research on correlation between Tahajud (night prayer) and human immunologic system. He did the research in psychoneuroimmunology discipline perspectives. It is the fact that many religious texts (Al-Quran and Hadits) encourage Muslims to do this prayer because it can cure illness. ${ }^{51}$ On the other hand, medical science says that doing activity in the midnight increases cortisol hormone that results in stress. He tried to find the relationship between the religious texts and science, because if science is true then the religious text is false. He found two categories of people who become better after the regularly practice the prayer and another group became worse. He found the clarification from his experiments that those who became better after the prayer were people who pray without pressure from others to do so; and conversely those who became worse are people who did prayer without of his own willing. ${ }^{52}$ The question for this experiment result is "did the people become better after the prayer because of the combination between the prayer itself and feeling relaxed?" or "did they become better just because simply they felt relaxed?", "can certain kind of meditation results in the same thing?" of course these questions cannot be answered unless -as Ruse says- inquiry begins.

What can be inferred from the dialogue of possibility contact and confirmation between science and religion is that science is not aimed to prove religious materials. However, by having religion and science to exist in human mind, one can broaden his religious horizon as well as

\footnotetext{
${ }^{49}$ Dhanani, 1

${ }^{50}$ Sholeh, 4.

${ }^{51}$ Sholeh, 1-2

${ }^{52}$ Sholeh, 1-11
} 
triggering science to explore more due to religious assumption towards nature.

From the dialogue in Western perspective as well as Islamic scholarly attitudes, such as al-Kindi, multi-disciplinary approach in Indonesian Islamic higher education must be operated by an openminded scholar, having al-Quran and Hadits as the foundation and source of scientific inquiry inspiration. Therefore, religion and science is still positioned in their own domain, but the contact between them is a trigger for the religious to broadened their horizon through scientific inquiry, like Mohamad Sholeh's work, and for scientists to put ethical foundation from religion to make use science in the society. Consequently, genres of new disciplines in Indonesian Islamic higher education should not be in competition resulting one to be left behind, such as what happened in Harvard. But, the genres aim to develop religious axiological dimension on scientific product in purpose of developing society.

\section{Pragmatism: A Critique to Relationship Between Science and Religion}

The relationship between science and religion is a never-ending discussion since both sides always have effective argument to show the "superiority" over another. As a critique to the debate between science and religion, it is better to show the use of each ism into practice, so human beings in general can be benefitted from science and religion. In pragmatism framework, one does not need to be occupied by metaphysic questions about the truth of science and or religion. One should accept different facts in life that is concrete and individual. Therefore, no one institution universalizes existence. In line with this notion, Alice Chipman said "that a religious attitude was indigenous in natural experience and that theology and ecclesiastical institution had benumbed rather than promoted it". 53 What can be seen from Chipman is that religious feeling is inherent in human life and human will find it in his personal experience. This notion influenced Dewey until finally he decided not to send his children to church anymore. ${ }^{54}$ Related to church, Dewey said that church was "the highest product of the interest of man in

\footnotetext{
${ }^{53}$ Cornel West, The American Evasion of Philosophy: A Genealogy of Pragmatism, The Wisconsin Project on American Writers (Madison, Wis.: University of Wisconsin Press, 1989), 78-79.

${ }^{54}$ Cornel West, 79
} 
man". ${ }^{55}$ What can be inferred from Alice and Dewey here is that human can have religious attitude by himself. Dewey said that "role of the church was to universalize itself and pass out of existence". 56 In other words, church can uniform human beings; and when this happens, individual existence which is unique and different from others' can be constrained.

I see Dewey's idea about church as a symbol of resistance to any attempt to group people. Dewey's rejection to religious institution appeared when he saw industrial capitalist in America between 18601900, a period when the population of America went doubled -or even more- because of the wave of immigrants. ${ }^{57}$ Labors with different group identity, oppression to labors, economic difficulties, are problems that needed to solve. Therefore, philosophy should not be exclusive and talk about a priori truth. Philosophy should be based on experience and connected to social problem. Therefore, Dewey came with a new philosophical paradigm that philosophy is a mode of wisdom that is convicting about values of choosing to do something. ${ }^{58}$ In short, Dewey's pragmatism is very practical in relation of human as subject and social problem as his object.

Regarding issue of religion, we can ask question about the practical dimension of it. Prayer can work in building one's confidence, relief stress, or some other psychological impact. However, merely prayer itself cannot be purposed to get what we pray for. Therefore, human need to work and do other real action to get real thing. I see that pragmatism does not reject religion, but it is just apologetic to it. From a lens of pragmatism, it is clear that something that actually works is not the religious text or something psychological, but real action does. Since pragmatism emphasizes on practical process and visible impact, the pre-

\footnotetext{
${ }^{55}$ Cornel West, The American Evasion of Philosophy: A Genealogy of Pragmatism, The Wisconsin Project on American Writers (Madison, Wis.: University of Wisconsin Press, 1989), 78-79

${ }^{56}$ Cornel West, The American Evasion of Philosophy: A Genealogy of Pragmatism, The Wisconsin Project on American Writers (Madison, Wis.: University of Wisconsin Press, 1989), 78-79

${ }^{57}$ Cornel West, The American Evasion of Philosophy: A Genealogy of Pragmatism, The Wisconsin Project on American Writers (Madison, Wis.: University of Wisconsin Press, 1989), 78-79

${ }^{58}$ Cornel West, 86
} 
conditioning situation -such as feeling or good mood- means nothing without its practical benefits.

What about multi-disciplinary approach in Islamic higher education from pragmatism framework? Islamic universities as unique individual entities should assert the foundations (al-Quran-Hadits) into secular science as the vehicle of scientific inquiry. Pragmatism in this sense would focus upon the final scientific product, whether it is -for instance- prophetic human development or prophetic management. Pragmatism here would not debate upon the truth in religious ultimate values, but it more focuses upon the impact of an academic effort for the society. Therefore, how the multi-disciplinary approach should work in each Islamic university should not be generalized or interfered by specific mechanism of how a scientific inquiry should work. Laissez faire et laissez passer, le monde va de lui même!

\section{E. Conclusion}

Confronting scientific authority upon religious authority leads to deathful examination upon each other. In one side, not all aspects of religion are falsifiable and testable. However, in another side, religion cannot be neglected in terms of its contribution for scientific inquiry. The contribution does not necessarily mean to prove religious claims. It is the fact that the scientific achievement within Islamic medieval period was influenced by Islamic doctrine for scientific inquiry. In this context, multi-disciplinary approach in Indonesian Islamic higher education cannot be seen as the use of scientific inquiry to seek proof of religious doctrines because this will result in the abandon of some beliefs.

The religious disciplines and secular disciplines must not overlap in dividing their area of study. The first challenge for the new scientific paradigm is that defining intersection between the two disciplines must be based upon spirit of broadening horizon to avoid between clash between the two. Apart from the epistemological debate, pragmatism perspective would challenge the long-term impact of the new paradigm. A pragmatist would question upon practical benefit of the new paradigm for society. Therefore, the challenge is for scholars under the paradigm's umbrella is to produce productive genres of sciences. 


\section{Bibliography}

Dhanani, Alnoor. (2006) "Muslim Philosophy and the Sciences." . Accessed 05/12/2017. http://iis.ac.uk/academic-article/muslimphilosophy-and-sciences.

Haught, John F. 1995. Science and Religion: From Conflict to Conversation. New York: Paulist Press,

Jackson, Elisabeth and Lyn Parker. "'Enriched with Knowledge': Modernisation, Islamisation and the Future of Islamic Education in Indonesia." RIMA: Review of Indonesian and Malaysian Affairs 42, no. 1 (2008): 21-53.

Karuvelil, George. "Science of Religion and Theology: An Existential Approach." Zygon ${ }^{\circledR}$ 47, no. 2 (2012): 415-37. http://dx.doi.org/10.1111/j.1467-9744.2012.01263.x.

Lukens-Bull, Ronald. 2013, Islamic Higher Education in Indonesia: Continuity and Conflict. First edition. ed. New York: Palgrave Macmillan,.

Popper, Karl Raimund and David Miller. 1983, A Pocket Popper. Fontana Pocket Readers. London: Fontana,.

Rahardjo, Didit Putra Erlangga. "Kurikulum 2013 Ditelanjangi Di Itb." Last modified Accessed. http://edukasi.kompas.com/read/2013/03/13/19402224/Kurikulu m.2013.Ditelanjangi.di.ITB.

Ruse, Michael. 2010, Science and Spirituality: Making Room for Faith in the Age of Science. Cambridge England; New York: Cambridge University Press.

Schwehn, Mark R. 1993, Exiles from Eden: Religion and the Academic Vocation in America. New York: Oxford University Press,.

Sholeh, Moh. 2012, Terapi Shalat Tahajud Menyembuhkan Berbagai Penyakit. Jakarta: PT. Mizan Publika. 
Multi-Disciplinary Approach in Indonesian Islamic Higher Education: A Western Perspective upon Epistemological Problem, Challenge, and Critique

Surabaya, UIN Sunan Ampel. "Paradigma Keilmuan." Last modified Accessed 2017. http://www.uinsby.ac.id/id/251/paradigmakeilmuan.html.

Syam, Nur. "Membangun Keilmuan Islam Multidisipliner." Accessed. http://nursyam.uinsby.ac.id/?p=754.

West, Cornel. 1989, The American Evasion of Philosophy: A Genealogy of Pragmatism. The Wisconsin Project on American Writers. Madison, Wis.: University of Wisconsin Press.

Yogyakarta, UIN Sunan Kalijaga. "Core Values." Last modified Accessed 2017. http://uin-suka.ac.id/page/universitas/29-corevalues. 